УДК 374.1

DOI https://doi.org/10.24919/2308-4863/34-2-35

\author{
Кіра ГОРЯЧЕВА, \\ orcid.org/0000-0003-1503-4425 \\ кандидат економічних наук, доиент, \\ провідний науковий співробітник \\ Військового інституту
}

Київського начіонального університету імені Тараса Шевченка

(Київ, Україна) horyachevakira@gmail.com

Олег БУРДЮГ, orcid.org/0000-0002-1319-4807 науковий співробітник

Військового інституту

Київського начіонального університету імені Тараса Шевченка (Київ, Україна)_burdug_@ukr.net

Юлія ТІТОМИР, orcid.org/0000-0002-3704-6550 молодший науковий співробітник

Військового інституту Київського начіонального університету імені Тараса Шевченка (Київ, Україна) andrii62ch@gmail.com

\title{
ВИЗНАЧАЛЬНІ МОМЕНТИ: ЗНАЧЕННЯ БАТЬКІВСЬКИХ ВІДГУКІВ ПІД ЧАС ПРОДАЖУ ПОСЛУГ ПРИВАТНИХ РЕПЕТИТОРІВ
}

Нині приватне академічне навчання для учнів шкільного віку набирає дедалі більших обсягів. У всьому світі значна кількість батьків купує додаткове навчання у комерційних постачальників, щоб покращити успішність свойх дітей. У багатьох країнах ией феномен можна розуміти як «страхову стратегію» «пруденційних» батьківських передбачень (Doherty, Dooley, 2017).

Приватне навчання - ие засіб, за допомогою якого батьки змушені діяти самостійно на шкільних ринках, щзо може пом'якшити батьківську тривогу щьодо відповідальності, одночасно максимізуючи результати та мінімізуючи ризики для своїх дітей. Український ринок приватних репетиторів розширюється в умовах, коли довіра батьків до шкільного персоналу як освітніх експертів є вразливою. Батьківська демократична логіка підштовхує їх вливати ресурси, які є в їхньому розпорядженні, у їхню педагогічну роботу, щуоб досягти результатів освіти, яких вони бажають для своїх дітей. Однак мало відомо про конкретні стратегії, які приватні постачальники репетиторів використовують для залучення батьків.

У статті наведено дослідження 160 відгуків батьків, опублікованих на веб-сайтах 19 приватних постачальників навчальних програм в Україні. Спираючись на конщепцію «відповідальних моментів» А. Гідденса та роботу 3. Баумана над переконанням прикладу однолітків разом з інструментами критичного аналізу дискурсу, ми стверджуємо, що відгуки батьків використовують емочійні заклики для побудови приватного навчання як вирішення відповідальних моментів батьків. Ми припускаємо, щуо ия емоційна основа перегукується з педагогічними уподобаннями домінуючого украӥнського середнього класу.

Для тих, хто шукає відгуки батьків, чия довіра до шкіл може бути пошкоджена через їхній невдалий досвід, рекомендачії однолітків можуть бути переконливими. Масив відгуків на веб-сайтах постачальників репетиторських послуг і вплив рекомендацій щчодо передових аспектів навчального досвіду створюють навмисно побудовану версію реальності, яка може запропонувати переконливий варіант для батьків, які намагаються розв'язати існуючу або потениійну проблему.

Ключові слова: відгук батьків, тіньова освіта, додаткова освіта, приватне навчання, патріотизм, відповідальні моменти. 


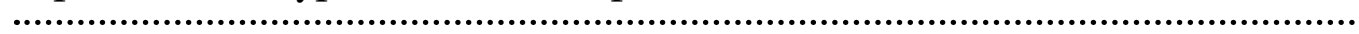

Kira HORIACHEVA,

orcid.org/0000-0003-1503-4425

PhD in Economics, Associate Professor,

Senior Research Fellow

Military Institute

of Taras Shevchenko National University of Kyiv

(Kyiv, Ukraine) horyachevakira@gmail.com

Oleg BURDYUG, orcid.org/0000-0002-1319-4807

Researcher

Military Institute

of Taras Shevchenko National University of Kyiv

(Kyiv, Ukraine)_burdug_@ukr.net

Yulia TITOMYR, orcid.org/0000-0002-3704-6550

Junior Research Fellow

Military Institute

of Taras Shevchenko National University of Kyiv,

(Kyiv,Ukraine)andrii62ch@gmail.com

\section{IN FATEFUL MOMENTS: THE APPEAL OF PARENT TESTIMONIALS WHEN SELLING PRIVATE TUTORING}

Today, private academic education for school-age students is gaining momentum. Around the world, a significant number of parents buy additional training from commercial providers to improve their children's performance. In many countries, this phenomenon can be understood as an "insurance strategy" of "prudential" parental predictions (Doherty, Dooley, 2017).

Private learning is a means by which parents, forced to act independently in school markets, can alleviate parental anxiety about responsibility while maximizing outcomes and minimizing risks to their children. Ukrainian's private tutoring market is expanding in a context where parents' trust in school personnel as educational experts is vulnerable. Simultaneously, a parentocratic logic is nudging parents to infuse the resource sat their disposal into their pedagogic work in order to achieve the educational outcomes that they wish for their children.

However, little is known about the specific strategies that private tutoring suppliers are using to attract prospective parents. This paper reports on a study of 160 parent testimonials published on the websites of 19 private tutoring suppliers in Ukraine. Drawing on Giddens'concept of fateful moments' and Bauman's work on the persuasion of the peer example, together with tools of critical discourse analysis, we argue that parent testimonials use emotional appeals to construct private tutoring as a resolution to parents'fateful moments.

In addition, we speculate that this emotional footing resonates with the pedagogic preferences of the dominant Ukrainian middle classes. For those who are looking for feedback from parents whose trust in schools may be damaged by their bad experiences, peer recommendations can be compelling. The array of feedback on tutoring websites and the impact of recommendations for advanced learning experiences create a deliberately constructed version of reality that can offer a compelling option for parents trying to solve an existing or potential problem.

Key words: parent testimonial, shadow education, supplementary education, private tutoring, parentocracy, fateful moments.

Постановка проблеми. У цій статті ми розглядаємо дискурсивну роботу з відгуками на вебсайтах постачальників приватних репетиторів щодо апеляції батьків як споживачів.

Феномен приватного навчання широко відомий як «тіньова освіта» або «приватна додаткова освіта». Він різниться за масштабом, інтенсивністю та режимом залежно від регіону. Цей процес є досить динамічним (Bray, 2009). В Україні масштаби репетиторської галузі швидко зроста- ють, дедалі більше сімей купують ці послуги. Крім того, різноманітність постачальників диверсифікується. Колись український ринок репетиторства шкільного віку мав насамперед коригувальний характер і неофіційно організовувався за принципом «домашнього господарства». Однак нині в Україні корпоративні моделі репетиторського бізнесу проводяться в багатьох містах і передмістях. Ці підприємства відомі своєю активною рекламою та діяльністю на ринку репетиторських 
послуг. За допомогою такої тактики постачальники продають батькам більш широкий спектр приватних репетиторських послуг.

Метою статті було дослідити соціологічну основу відгуків батьків на веб-сайтах приватних навчальних закладів. Наш аналіз відгуків свідчить про те, що приватне навчання проводиться як рішення для батьків, незадоволених успіхом дітей у школі. Довіра між батьками та школами стає дедалі вразливішою, і ці відгуки стають підставою для активізації зацікавленості батьків, які шукають альтернативу. У цій статті ми пояснюємо, як відгуки батьків прагнуть породити довіру до приватних постачальників репетиторів.

Аналіз досліджень. Проблемою щодо вивчення батьківських відгуків на веб-сайтах приватних навчальних закладів як соціологічного підгрунтя для реалізації репетиторських послуг займалися А. Гідденс, 3. Баумен, П. Браун, Ф. Різві, Б. Лінгард, Т. Вільсон, але нині вона $є$ нагальною, недослідженою.

Виклад основного матеріалу. Реклама приватного навчання 3'являється повсюди. Під час дослідницького проекту 3 приватного навчання ми знаходили таку рекламу на білбордах і ліхтарних стовпах біля шкіл, у шкільних бюлетенях, на сайтах батьківських соціальних мереж, у громадських газетах, на телебаченні. Така цільова інтернет-реклама знаходить батьків-споживачів i призводить до більш широкого використання маркетингових засобів на веб-сайтах.

У цій статті нас особливо цікавлять відгуки батьків, які відгукуються на подібну рекламу. Відгуки - це загальноприйняті маркетингові засоби на веб-сайтах постачальників (Davis, 2013), які виконують роль схвалення споживачів продукту. Ця тактика широко рекомендована в популярній бізнеслітературі для маркетингу не тільки приватного навчання, але й освіти загалом та інших послуг, таких як охорона здоров'я (Entrepreneur, 2012).

Відгуки, які використовуються для приватного навчання в Україні, $є$ схваленнями «типових» батьків, а не «відомих» батьків. Сила прагнень, використана цим типом відгуку, призводить до схожості між тим, хто дає відгук, і потенційним клієнтом. Авторитет схвалення грунтується на успішному досвіді, який «хтось на зразок мене» мав із продуктом.

Так, американське дослідження (Rice, 2015: 121-141) показало свідчення типових батьків, які обіцяють потенційним клієнтам продуктів шкільного навчання в інтернеті успіх у вирішенні батьківських проблем, враховуючи досвід їхніх дітей у регулярному навчанні. Однак ця форма марке- тингу обіцяє рівноцінний успіх; вона також пропонує членство у спільноті однодумців. Окрім впливу на купівельну поведінку окремих споживачів, реклама на основі відгуків допомагає створити моделі споживання та ідентичності для певних груп населення (Martin, Wentzel, Tomczak, 2008: 29-43).

В Україні батькам, які мають дітей шкільного віку, продається все більший спектр репетиторських послуг, який охоплює широкий діапазон навчальних дисциплін. Регулярно переглядаючи засоби масової інформації під час нашого дослідження $з$ приватного навчання, ми виявили лише позитивні оцінки репетиторських послуг і продуктів для дітей 3 проблемами читання (Frost, 2017). Натомість ринки репетиторства для вищих навчальних закладів і тих, хто вивчає англійську мову, $є$ більш суперечливим фронтом для батьківських дискусій.

Кониептуалізація батьківського відгуку як взаємної рекомендації в експертній якості

Дослідники визначили «батьківську демократію» логічною в процесі навчання. «Батьківська демократія» - це система, в якій освіта дитини повинна відповідати багатству та бажанням батьків, а не здібностям і зусиллям учня, на відміну від меритократії, яка розподіляє освітні та фінансові винагороди відповідно до здібностей і зусиль. «Батьківська демократія» - це соціологічна концепція, яка відображає політичну ідеологію і вплинула на організацію шкіл.

Термін «батьківська демократія» спочатку використовувався для визначення соціально-політичної ідеології, яка легітимізувала неоліберальну освітню політику, розгорнуту в 1980-х роках. За цією ідеологією результати навчання розподіляються відповідно до засобів і побажань батьків, а не від здібностей і зусиль та заслуг дитини (Brown, 1990: 65-86). 3 тих пір цей термін поширюється на інтервенційну практику виховання дітей (Barrett De Wiele, Edgerton, 2016) як узгоджене виховання (з репетиторством або без нього) дітей домінуючого середнього класу в капіталістичному середовищі.

В українському середовищі батьківсько-демократичний підхід укоренився в контексті деяких відмінних рис національного освітнього сектору, а також неоліберальних політичних установок, поширених у суспільствах на міжнародному рівні. Загалом спостерігається ерозія довіри до послуг державного сектору, включаючи надання державою освіти (Pusey, 2003). Схильність батьків до виходу за межі державної освіти заохочується застосуванням маркетингових заходів 
у сфері освіти (Rizvi, Lingard, 2010). Поза формальним шкільним навчанням спостерігається різке зростання кількості організацій 3 надання послуг освіти. Вони виступають в якості гравців в освітньому секторі, а саме в підсекторі репетиторства. Це явище розповсюджене на міжнародному рівні (Ball, 2017).

«Батьківська демократія» наділяє батьків свободою та відповідальністю. Як зазначалося в Британії наприкінці 1980-х років, батьківськодемократичний підхід означає, що незалежний споживач може вільно відпочивати на курорті, а не інвестувати в навчання. При цьому тільки він сам буде винний у результатах навчання своїх дітей (Brown, 1990: 65-86).

Ми стверджуємо, що вибір батьками послуг приватного репетитора свідчить про недовіру батьків до освіти як системи експертних знань. Експертні системи - це системи технічних знань і знань, які організовують та підтримують соціальне й матеріальне середовище. Довіра людей до цих систем залежить від віри у правильність системи. Коли експертну систему сприймають як узгоджену та надійну, можна встановити довіру та посилити емоційне відчуття безпеки у своєму існуванні - те, що А. Гідденс (Giddens, 1991) називає «онтологічною безпекою».

Онтологічна безпека - це стабільний психічний стан, який походить від почуття наступності щодо подій у житті. Для того, щоб батьки довіряли школам і вчителям своїх дітей (як представникам експертної системи навчання), спеціалісту, технічним знанням із таких питань як педагогіка, навчанню та навчальній програмі, вони повинні вірити в те, що навчальний досвід їхніх дітей $\epsilon$ надійним і заснованим на дійсних технічних знаннях. Однак батьки середнього класу все частіше втручаються в освіту своїх дітей, щоб зняти напругу i занепокоєння щодо здатності шкіл обслуговувати їх дітей таким чином, щоб зберегти або покращити їхнє соціальне становище. Втручання батьків та управління освітою їхніх дітей може бути симптомом руйнування довіри до технічних знань освіти як експертної системи.

Довіра до експертних систем вразлива в ситуаціях, коли люди стикаються з представниками експертних систем - так званих «точок доступу». Для батьків «невдалий досвід» під час взаємодії з представниками освітньої експертної системи (такими як директори чи вчителі) може вплинути на ступінь їхньої довіри. Багаторазові невдалі випадки можуть призвести до припинення довіри до освітньої експертної системи та поставити батьків перед дилемою щодо шляхів вирішення проблеми.
Батьків турбує, що їхня дитина не отримає балів, необхідних їй для вступу до закладу вищої освіти, або в разі наявності вад у дитини, на їхню думку, їй надається недостатня підтримка у навчанні, яка перешкоджає здатності дитини успішно відвідувати школу. Такі ситуації можуть викликати тривогу та побоювання щодо того, як вирішити суть дилеми. Ці визначальні моменти мають велике значення, і людина відчуває себе на перехресті з точки зору загального планування життя. У визначальні моменти люди часто поводяться рефлексивно. Деякі батьки можуть звести проблему до мінімуму, припускаючи, що з часом здатність дитини розвиватиметься і проблему буде вирішено самостійно. Інші можуть бути прихильниками використання власних робочих програм (наприклад, 3 мереж Інтернет). Деякі з батьків можуть припустити, що залучення послуг приватного репетитора зможе вирішити проблему.

Вибір батьків, зроблений рефлексивним способом, сприяє постійній узгодженості самоідентичності та підтримці онтологічної безпеки людини. Так, вибір батьків придбати приватне навчання може розглядатися як вирішення дилеми. Необхідно зрозуміти, як вибір приватного навчання може бути обраним у визначальний момент. У соціально-політичному контексті, коли батьки менш схильні довіряти школі та їі представникам і діють організовано як громадяни, які відповідають за вибір, батьківська демократія підштовхується до того, щоб прийняти відповідальність за академічні проблеми своїх дітей. Відгук батьків викликає особливий інтерес 3 огляду на тенденцію шукати приклад, а не суто авторитет.

Для батьків, чия довіра до шкіл зменшується, відгук, схожий з відгуками інших батьками на приватному веб-сайті репетиторів, може бути більш значущим, ніж авторитет рішення вчителя щодо академічної проблеми дитини. Тут дискурсивна сила батьківського відгуку підноситься як важливий батьківський досвід. Подібні з іншими батьківські перспективи можуть бути достатніми, щоб переконати батьків мобілізувати свої ресурси за допомогою приватного навчання.

Маркетингова література розрізняє використання емоційних відгуків і раціональних відгуків у рекламі. Існує обмежене розуміння соціологічних механізмів, які отримують певні відповіді від одержувачів маркетингових текстів. Тому наш аналіз відгуків виходить за рамки класифікації конкретних звернень як раціональних чи емоційних.

Протягом 2018-2019 років ми аналізували вебсайти 19 постачальників послуг репетиторів, які працюють на українському ринку. Веб-сайти були 
повторно відвідані нами у 2020 році. Хоча деякі 3 них були оновлені, жодних суттєвих змін, які б стосуються нашого аналізу, не відбулося. Наш аналіз складається $з$ трьох етапів. По-перше, ми описували текстові особливості відгуків, зосереджуючи увагу на тому, як саме побудована розповідь батьків про їхній досвід використання репетиторських послуг. По-друге, ми зосереджувалися на інтерпретації веб-сайтів і їх взаємозв'язку із соціальними процесами. Перший і другий етапи наводилися одночасно. Також ми надавали пояснення стосунків між батьками як споживачами репетиторських послуг і соціальним контекстом ринку репетиторів стосовно вибору приватного репетитора як стратегії вибору у вирішальний момент.

Розуміючи приватне навчання як один із багатьох варіантів, доступних для батьків, коли вони зорієнтовані на труднощі у навчанні своїх дітей, ми повторюємо твердження Вільсона та Карлсена (Wilson, Carlsren, 2016: 24-46) про те, що веб-сайти «не просто описують поле вибору; вони діють, щоб сформувати доступність, значення та природу такого вибору». У цій роботі нас особливо цікавить, як відгуки та рекомендації можуть формувати вибір батьків на ринках репетиторських послуг.

Проведений нами аналіз показав, що веб-сайти 19 постачальників становили дві окремі групи. Перша група складалася 316 індивідуальних репетиторів, малих навчальних центрів або більших (транснаціональних) навчальних центрів, які обслуговували дітей шкільного віку в різних академічних сферах (найчастіше це англійська мова та математика). Ці постачальники спрямовані на широке коло батьків, які насамперед зацікавлені у тому, щоб допомогти своїм дітям «наздогнати» шкільну програму та підтримати їхній емоційний добробут. Ці постачальники здебільшого пропонували домашню роботу або власні матеріали, які відображають українську шкільну програму. Ми знайшли відгуки батьків на 13 із 16 веб-сайтів постачальників. Кількість відгуків на кожному веб-сайті варіювалася від двох-трьох до десяти і більше. Відгуки кожного веб-сайту були збережені для створення набору даних для аналізу.

Другу групу складали три академічні тренерські заклади. Ця група постачальників мала вузький цільовий ринок, здебільшого орієнтований на батьків, яких турбує академічна майстерність їхніх дітей і високі показники селективного вступного іспиту до школи та тестів (ЗНО). Відгуків батьків ми не знайшли на веб-сайтах цих постачальників; натомість ці веб-сайти надавали фактичну інформацію про зміст послуг та академічні результати попередніх учнів (хоча існували деякі відгуки учнів, які висловлювали радість від своїх високих досягнень). Тобто їх заклик був раціональнішим, а не емоційним. Відгуки були повідомленнями від першої особи, вони мали довжину від одногодвох речень до довших блоків тексту приблизно в 200 слів. Зрозуміло, що всі відгуки були написані на підтримку певної служби репетиторства.

Висновки. Відгуки стосувалися чотирьох груп учасників: батьків, дітей, репетиторів (сама послуга та ії результати для дітей) $\mathrm{i}$ школи. Батьки, діти та репетитори були описані позитивно, тоді як в описах шкільного персоналу було використано більше неоднозначних суджень.

Батьки здебільшого були задоволені послугами репетитора, найчастіше описуючи почуття радості та вдячності. По-перше, батьки були задоволені результатами репетиторства для своїх дітей (приклад: «Ми в захваті від того, що табель Олени - найкращий із усіх!»). По-друге, батьки були вдячні репетитору за його роль у явному вдосконаленні їхніх дітей (приклад: «Андрій без вас не прогресував би так само, як з вами).

У багатьох батьків існувало приписування причинності; інші фактори, які могли сприяти поліпшенню стану дитини (наприклад, продовження навчання у школі) не згадувалися, а будьякі покращення для дитини без винятку приписували репетитору. Граматичні підсилювачі такі як «дуже» та «дійсно» батьки часто використовували для переказу свого досвіду (31 використання «дуже» і 58 вживань «дійсно» були пов'язані 3 позитивним ставленням батьків і дітей у 160 зразках текстів). Такий позитивний контекст характеризує батьків як задоволених клієнтів і може бути привабливим для тих, хто шукає доказів того, що навчання може бути позитивним і вартим вибору.

Дітей представляли реципієнтами 3 відсутністю або дефіцитом академічних здібностей чи самовпевненості. Описи батьків часто подавалися «ускладненою» розповіддю, в якій репетиторство було остаточним рішенням проблеми. Слово «покращення» батьки здебільшого обирали для складання своїх звітів. Найчастіше вони описували покращення впевненості у собі, академічні результати та конкретні академічні здібності. Загальновживаним було слово «зараз», яке свідчило про те, що «до» репетиторства було проблемою, що репетиторство певною мірою вирішило іiі.

Постійно повідомлялося, що діти користувалися послугами репетиторів. Батьки як особи, які публікують відгуки, були сприйняті як стурбовані та залучені до успіху своїх дітей у школі, а вдосконалення своїх дітей вони приписували лише 
репетиторам. Відгуки були передбачуваними таким чином, що вони описували кілька подібних вад (діагностика) та кілька подібних результатів для своїх дітей (лікування). Таким чином, фірми-репетитори використовували такі відгуки для вирішення проблем, щоб орієнтуватися на батьків, які прагнуть виправити ситуацію через втручання у навчання своїх дітей. Навантажені емоціями відгуки зустрічалися нечасто і не мали грунтовних статистичних даних щодо результатів репетиторства. Ці емоційні відгуки без посилання на зовнішній показник якості $є$ загальним явищем у маркетингу послуг для батьків (Johns, English, 2016: 65-72).

Послуги репетиторів у відгуках батьків були подані у двох аспектах: співробітники репетиторських закладів і педагогічна технологія, яку використовували репетитори. Відгуки формувалися на користь репетиторської підтримки, а репетитори були описані тільки позитивно. Відносини між викладачем і дитиною були в центрі уваги багатьох відгуків. Хоча оцінки батьків щодо якості репетитора були одноманітними, результати, які сподобалися у педагогічному плані, різнилися. Наприклад, деякі зазначали про «спеціально підібрану» та «творчу» педагогічну технологію; інші були задоволені незалежністю, якій, очевидно, сприяла програма репетиторів.

Батьки зробили кілька випадкових відгуків про школи. Репетиторство було подано як «ліки» від явних шкільних вад. Наприклад, один із батьків зазначив, що програма репетиторства була корисною, оскільки вона давала допомогу з домашнім завданням там, де цього не робила школа.

При публікації відгуків, які представляють опосередковану критику шкіл, постачальники репетиторів позиціонують себе як надійного експерта в галузі освіти та обслуговування клієнтів. Там, де відгуки можуть представляти школи потенційно самозадоволеними, турботливий, терплячий і залучений вихователь виходить на перший план; де школи представлені як такі, що нехтують батьківськими проблемами, репетиторські компанії представлені як протилежність - як уважні та чуйні союзники для батьків. Цей бінарний файл, можливо, сприяє активації зацікавленості тих батьків, які прагнуть пояснити труднощі своєї дитини у школі та шукають доказів того, що приватне навчання буде вирішенням цих проблем. Отже, відгуки ілюструють задоволення батьків роботою приватних репетиторів в обслуговуванні освітніх труднощів своїх дітей, а також позиціонують школи як нездатні чи такі, які не бажають надавати індивідуальні послуги.
Тепер ми переходимо до пояснення соціальних та інституційних умов, які впливають на цю дискурсивну роботу відгуків батьків. Відгуки - це вибіркове штучне подання розповідей батьків, пов'язаних із труднощами їхніх дітей у навчанні. Ми стверджуємо, що для цих батьків (автентичних чи вигаданих) репетиторство було відповіддю на їхній власний «невдалий досвід» із представниками освітньої системи, здебільшого школами та вчителями. У будь-якому випадку вибір послуг репетиторів свідчить про зниження довіри до здатності школи задовільно вирішувати проблеми батьків та їхніх дітей. Ці батьки зіткнулися 3 дилемою щодо того, як діяти далі, вирішуючи труднощі дитини.

Для батьків труднощі у навчанні або досягнення дитини можуть викликати занепокоєння та побоювання щодо того, яким чином ці складнощі вплинуть на майбутнє їхньої дитини. Чи досягне дитина результатів без втручання? Чи вчитель вирішить проблему? Як проблема вплине на можливості дитини в майбутньому? Таким чином потенціал дитини щодо досягнення високих досягнень може викликати тривогу. Чи адекватна шкільна програма для реалізації цього потенціалу? Які додаткові можливості для навчання повинна надавати сім'я? Перед батьками постає безліч проблем, страхів та уявних результатів. Рішення батьків у визначальний момент можна вважати надзвичайно важливим у контексті моралізації батьківства. Неоліберальна логіка підтримує прагнення та активне батьківство (Ball, 2017). Так, батьків підштовхують взяти на себе відповідальність за вибір, який вони роблять для своїх дітей, і за наслідки такого вибору.

Ми також розуміємо таку підвищену чутливість до ризиків і можливостей освітніх результатів у контексті глобалізованого світу, в якому посилена економічна та політична взаємозалежність перетворила усвідомлене значення повноважень, наданих дітям системою освіти. Багато літературних джерел зазначають про несправедливий розподіл наслідків глобалізації. Як зазначає Халлак (Hallak, 2000: 21-40), є «ті, хто глобалізується, хто глобалізований і хто залишається осторонь».

Конкурентні глобальні ринкові сили визначають, що соціальні та економічні перспективи людей залежать від їхньої здатності бути кваліфікованими та гнучкими працівниками (Lingard, 2013). Батьки побоюються, що діти, які не можуть досягти успіху в навчанні, дійсно можуть бути пропущені і приєднаються до «легіонів відкинутих, знецінених людей, які формують зростаючу планету нерелевантного» (Castells, 2000: 5-24). 
Підсумовуючи значення впливу на майбутне дитини здобутих нею освітніх навичок, варто зазначити, що «це посилило тривогу серед батьків середнього класу щодо їхньої здатності зберігати своє місце (соціально-економічний статус) у суспільстві та забезпечувати освітні переваги для своїх дітей» (Power, et al., 2003).

Привабливість та авторитет однорангової рекомендації підкріплюються сучасним бажанням знати, як звичайні особи орієнтуються в подібних проблемах (Bauman, 2000). Приклад i погляди однолітків приваблюють. Наш аналіз демонструє, як відгуки однолітків можуть накопичувати силу, що породжує довіру до потенціалу приватного навчання та формують вибір батьків для здійснення вибору на користь приватного навчання. Опосередковані відгуки, в яких батьки описують конкретний і послідовний набір проблем, пов'язаних з освітою їхніх дітей, дозволяють учасникам тестування уявити себе радником, який зазнає тих самих успіхів із використанням послуг приватного навчання.

Подібним чином дослідники (Jeacle, Carter, 2011: 293-309) проаналізували довіру, яка виникла через систему рейтингу веб-сайту для подорожей в інтернеті, стверджуючи, що рейтинги користувачів постачальників туристичних послуг будували «експертні системи, опосередковані інтернетом». У їхньому випадку саме розрахункові практики, пов'язані з системою рейтингу зірок, у поєднанні 3 коментарями мандрівників про їхній досвід постачальників створили довіру (а не довіру, яку традиційно покладають на туристичних агентів).

Більше того, (Jeacle, Carter, 2011: 293-309) зазначають, що опосередковані інтернетом експертні системи викликають скептицизм щодо більш офіційних форм експертизи, але при цьому перевага надається думкам інших користувачів. Наші висновки є паралельними, зокрема вони стосується того, де відгуки батьків критикують вчителів і школи. Тобто інколи батьківські відгуки, передані постачальникам репетиторських послуг на приватному ринку, сприяють «комерціалізації довіри». Це вже не той випадок, коли експерти iз традиційної освіти працюють без конкуренції; батьки стикаються з безліччю відгуків, які конкурують між собою, і можуть ретельно вивчити більшу кількість варіантів, перш ніж вирішувати, кому вони можуть довіряти.

Ми зазначаємо про переважне використання емоційних, а не раціональних відгуків. Хоча деякі батьки згадували про функцію репетиторства для рішення труднощів своєї дитини, здебільшого відгуки були зосереджені на позитивних почуттях, пов'язаних із репетиторством: щастя вилікуваної дитини та її батьків; теплота і доброзичливість вихователя; задоволення від занять із репетиторами. В контексті суперечок щодо використання репетиторства в українському суспільстві помітно, що акцент на формуванні навчального середовища та позитивних почуттях дітей до репетиторства відображає те, що було визначено як усталений батьківський дискурс домінуючої соціальної групи. Це форма виховання, вироблена «сучасними прогресивними батьківськими дискурсами, які підтримують слабкі рамки відносин між батьками і дітьми крізь мовчазні режими дисципліни, акцент на грі, виховання «цілісної дитини» та опір явній конкуренції» (Sriprakash, Proctor, Betty, 2016: 246-441).

Спеціалізований характер знань і багатоманітність наявних тверджень про знання створюють дилему конкуруючих знань (Giddens, 1990). Більшість батьків не знають про навчальні програми та педагогічні інструменти постачальників репетиторських послуг, не мають достатнього досвіду для адекватної оцінки. Тому вибір батьків для використання приватного репетиторства здебільшого грунтується на інформації, яка надається постачальниками репетиторів. Через це для батьків, які шукають рішення, може бути складно 3 впевненістю зробити вибір. У цьому контексті рефлексивність скеровує людей вибирати, чиїм/ яким знанням довіряти.

Згідно 3 Холмсом (Holmes, 2010: 139-154) рефлексивність нерозривно пов'язана 3 емоціями, таким чином люди здебільшого покладаються на «почуття довіри, симпатії чи задоволення або їх протилежності». Уподобання тих, хто надає відгуки на основі емоційної реакції на навчання, дають впевненість у тому, що вибір буде правильним. Для тих, хто приймає відгуки, читання емоційно заряджених звітів однолітків про репетиторство може забезпечити надію та оптимізм у власні вирішальні моменти, а також допомогти породити довіру до постачальників репетиторських послуг як експертів із знань, здатних вирішити проблеми дітей.

Це дослідження доповнює зростаючу кількість емпіричних досліджень, які описують способи, за допомогою яких приватні навчальні постачальники звертаються до інших груп споживачів на міжнародному рівні. Дослідження в Гонконзі показали, як постачальники репетиторських послуг звертаються до підлітків із зображеннями бого-вихователів чи вихователів-зірок, які знають все, що можна знати про успіх на іспитах із високими рейтингами (Koh, 2014: 803-819). 
Дослідження веб-сайтів репетиторів для дорослих росіян виявило ознаки високопоставлених або дуже популярних репетиторів англійської мови (Kozar, 2015: 354-368). До цього набору емпіричних розумінь привабливості репетиторських продуктів це дослідження додає розуміння того, як постачальники репетиторських послуг для дітей шкільного віку в українських регіонах емоційно звертаються до батьків через відгуки однолітків. Ми припустили, що тактику можна тлумачити в соціальному контексті, що погіршує довіру до інституціоналізованого шкільного навчання; чи працює ця тактика дію на потенційних споживачів - це інше питання, хоча їх часте використання на цьому ринку може свідчити про це.

Результати цього дослідження такожє підставою для подальшого аналізу того, як реакція однолітків рефлектує та/або спричиняє занепокоєння батьків. Це цікаво для більш розгорнутого дискурсу щодо формування відповідального батьківського «я» в пізньомодерних або неоліберальних умовах. Підсумовуючи тезу щодо приватного навчання, необхідно підкреслити, що корпоратизація репетиторських послуг як форми навчання та супутнє розповсюдження реклами є ознаками нового потужного гравця у громадській уяві українців, який стоїть за реаліями емпіричного світу шкільного навчання.

\section{СПИСОК ВИКОРИСТАНИХ ДЖЕРЕЛ}

1. К. Doherty, K. Dooley. 2017. "Responsibilising Parents: The Nudge Towards Shadow Tutoring". British Journal of Sociology of Education. doi: 10.1080/01425692.2017.1377600.

2. Bray M. 2009. Confronting the Shadow Education System. What Government Policies for What Private Tutoring? Paris : International Institute for Educational Planning.

3. Davis J. 2013. "Educational Legitimation and Parental Aspiration: Private Tutoring in Perth, Western Australia". $\mathrm{PhD}$ diss., University of Western Australia.

4. Entrepreneur. 2012. Tutoring and Test Preparation: Step-by-Step Startup Guide. New-York : Entrepreneur Press.

5. Rice M. F. 2015. "Rhetorical Constructions of Parents by Online Learning Companies: A Study of Parent Testimonials". In Exploring Pedagogies for Diverse Learners Online (Advances in Reaserch on Teaching), edited by M. F. Rice, 121-141. United Kingdom: Emerald.

6. B. A. S Martin., D. Wentzel, T. Tomczak. 2008. "Effects of Sustebility to Normative Influence and Type of Testimonial on Attitudes toward Print Advertising". Journal of Advertising 37 (1): 29-43. doi: 10.2753/JOA0091-3367370103.

7. Frost C. 2017. "Dyslexia Study Call in Schools". The Courter Mail, March, 11.

8. Brown P. 1990. "The 'Third Word': Education and the Ideology of Parentocraty". British Journal of Sociology of Education 11 (1): 65-86. doi: 10.1080/0142569900110105.

9. Barrett De Wiele, C. E., J. D. Edgerton. 2016. "Parentocraty Revisited: Still a Relevant Concept for Understanding Middle Class Educational Advantage?” Interchange 47: 189-210. doi:10.1007/s10780-015-9261-7.

10. Pusey M. 2003. The Experiences of Middle Australia. Cambridge : University Press.

11. F. Rizvi, B. Lingard. 2010. Globalising Education Policy. Oxon : Routledge.

12. Ball S. 2017. The Education Debate. $3^{\text {rd }}$ ed. Bristol : Polity Press.

13. Giddens A. 1991. Modernity and Self-Identity: Self and Society in the Late Modern Age. Stanford, California : Stanford University Press.

14. Wilson T. S., R. L. Carlsren. 2016. "School Marketing as a Sorting Mechanism: a Critical Discourse Analysis of Charter School Websites". Peabody Journal of Education 91 (1): 24-46. doi:10.1080/0161956X.2016.1119564.

15. Johns R., R. English. 2016. "Transition of Self: Repositioning the Celebrity Brand through Social Media - the Case of Elizabeth Gilbert”. Journal of Business Research 69 (1): 65-72. doi:10.1016/j.jbusres.2015.07.021.

16. Ball S. 2017. The Education Debate. 3rd ed. Bristol : Polity Press.

17. Hallak J. 2000. "Globalisation and Its Impact on Education". In Globalization, Educational Transformation and Societies in Transition, edited by T. Mebrahtu, M. Crossley, D. Johnson, 21-40. Oxford : Symposium Books.

18. Lingard B. 2013. Politics, Policies and Pedagogies in Education: The Selected Works of Bob Lingard. Oxon : Routledge.

19. Castells M. 2000. "Materials for an Exploratory Theory of the Network Society". British Journal of Sociology of Education 51 (1): 5-24. doi:10.1080/000713100358408.

20. Power S., T. Edwards, G. Whitty, V. Wigfall. 2003. Education and the Middle Class. Berkshire : McGraw-Hill Education. https://ebookcentral.proquest.com/.

21. Bauman Z. 2000. Liquid Modernity. London : Polity Press.

22. Jeacle I., C. Carter. 2011. "In TripAdvisor We Trust: Rankings, Calculative Regimes and Abstract Systems". Acounting, Organizations and Society 36 (4-5): 293-309. doi:10.1016/j.aos.2011.04.002.

23. Sriprakash A., H. Proctor, H. Betty. 2016. "Visible Pedagogic Work: Parenting, Private Tutoring and Educational Advantage in Australia". Discourse: Studies in the Cultural Politics of Education 37 (3): 246-441. doi: 10.1080/ 01596306.2015.1061976.

24. Giddens A. 1990. Consequences of Modernity. Stanford : Stanford University Press.

25. Holmes M. 2010. “The Emotionalization of Reflexivity”. Sociology 44 (1): 139-154. doi:10.1177/0038038509351616.

26. Koh A. 2014. "The "Magic" of Tutorial Centres in Hong Kong: an Analysis of Media Marketing and Pedagogy in a Tutorial Centre". International Review of Education 60 (6): 803-819. doi: 10.1007/s11159-014-9460-y. 
27. Kozar O. 2015. "Discursive Practices of Private Online Tutoring Websites in Russia”. Discourse: Studies in the Cultural Politics of Education 36 (3): 354-368. doi: 10.1080/01596306.2013.871238.

\section{REFERENCES}

1. Doherty K., K. Dooley. 2017. "Responsibilising Parents: The Nudge Towards Shadow Tutoring”. British Journal of Sociology of Education. doi: 10.1080/01425692.2017.1377600.

2. Bray M. 2009. Confronting the Shadow Education System. What Government Policies for What Private Tutoring? Paris : International Institute for Educational Planning.

3. Davis J. 2013. "Educational Legitimation and Parental Aspiration: Private Tutoring in Perth, Western Australia". PhD diss., University of Western Australia.

4. Entrepreneur. 2012. Tutoring and Test Preparation: Step-by-Step Startup Guide. New-York : Entrepreneur Press.

5. Rice M. F. 2015. "Rhetorical Constructions of Parents by Online Learning Companies: a Study of Parent Testimonials". In Exploring Pedagogies for Diverse Learners Online (Advances in Reaserch on Teaching), edited by M. F. Rice, 121-141. United Kingdom: Emerald.

6. Martin B. A. S., D. Wentzel, T. Tomczak. 2008. "Effects of Sustebility to Normative Influence and Type of Testimonial on Attitudes toward Print Advertising”. Journal of Advertising 37 (1): 29-43. doi: 10.2753/JOA0091-3367370103.

7. Frost C. 2017. "Dyslexia Study Call in Schools". The Courter Mail, March, 11.

8. Brown P. 1990. “The 'Third Word': Education and the Ideology of Parentocraty”. British Journal of Sociology of Education 11 (1): 65-86. doi: 10.1080/0142569900110105.

9. Barrett De Wiele, C. E., J. D. Edgerton 2016. "Parentocraty Revisited: Still a Relevant Concept for Understanding Middle Class Educational Advantage?” Interchange 47: 189-210. doi: 10.1007/s10780-015-9261-7.

10. Pusey M. 2003. The Experiences of Middle Australia. Cambridge : University Press.

11. Rizvi F., B. Lingard. 2010. Globalising Education Policy. Oxon : Routledge.

12. Ball S. 2017. The Education Debate. $3^{\text {rd }}$ ed. Bristol : Polity Press.

13. Giddens A. 1991. Modernity and Self-Identity: Self and Society in the Late Modern age. Stanford, California : Stanford University Press.

14. Wilson T. S., R. L. Carlsren. 2016. "School Marketing as A Sorting Mechanism: a Critical Discourse Analysis of Charter School Websites". Peabody Journal of Education 91 (1): 24-46. doi: 10.1080/0161956X.2016.1119564.

15. Johns R., R. English. 2016. "Transition of Self: Repositioning the Celebrity Brand through Social Media - the Case of Elizabeth Gilbert”. Journal of Business Research 69 (1): 65-72. doi: 10.1016/j.jbusres.2015.07.021.

16. Ball S. 2017. The Education Debate. 3rd ed. Bristol : Polity Press.

17. Hallak J. 2000. "Globalisation and Its Impact on Education". In Globalization, Educational Transformation and Societies in Transition, edited by T. Mebrahtu, M. Crossley, D. Johnson, 21-40. Oxford : Symposium Books.

18. Lingard B. 2013. Politics, Policies and Pedagogies in Education: The Selected Works of Bob Lingard. Oxon : Routledge.

19. Castells M. 2000. "Materials for an Exploratory Theory of the Network Society". British Journal of Sociology of Education 51 (1): 5-24. doi: 10.1080/000713100358408.

20. Power S., T. Edwards, G. Whitty, V. Wigfall. 2003. Education and the Middle Class. Berkshire : McGraw-Hill Education. https://ebookcentral.proquest.com/.

21. Bauman Z. 2000. Liquid Modernity. London : Polity Press.

22. Jeacle I., C. Carter. 2011. "In TripAdvisor We Trust: Rankings, Calculative Regimes and Abstract Systems". Acounting, Organizations and Society 36 (4-5): 293-309. doi: 10.1016/j.aos.2011.04.002.

23. Sriprakash A., H. Proctor, H. Betty. 2016. "Visible Pedagogic Work: Parenting, Private Tutoring and Educational Advantage in Australia". Discourse: Studies in the Cultural Politics of Education 37 (3): 246-441. doi: 10.1080/ 01596306.2015 .1061976 .

24. Giddens A. 1990. Consequences of Modernity. Stanford : Stanford University Press.

25. Holmes M. 2010. “The Emotionalization of Reflexivity”. Sociology 44 (1): 139-154. doi: 10.1177/0038038509351616.

26. Koh A. 2014. "The "Magic" of Tutorial Centres in Hong Kong: an Analysis of Media Marketing and Pedagogy in a Tutorial Centre". International Review of Education 60 (6): 803-819. doi: 10.1007/s11159-014-9460-y.

27. Kozar O. 2015. "Discursive Practices of Private Online Tutoring Websites in Russia". Discourse: Studies in the Cultural Politics of Education 36 (3): 354-368. doi: 10.1080/01596306.2013.871238. 